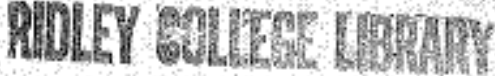

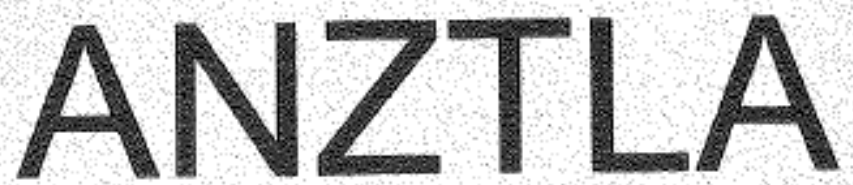

NOT TO EE ML BOVEE FroM THE LIBRARY

No. 29
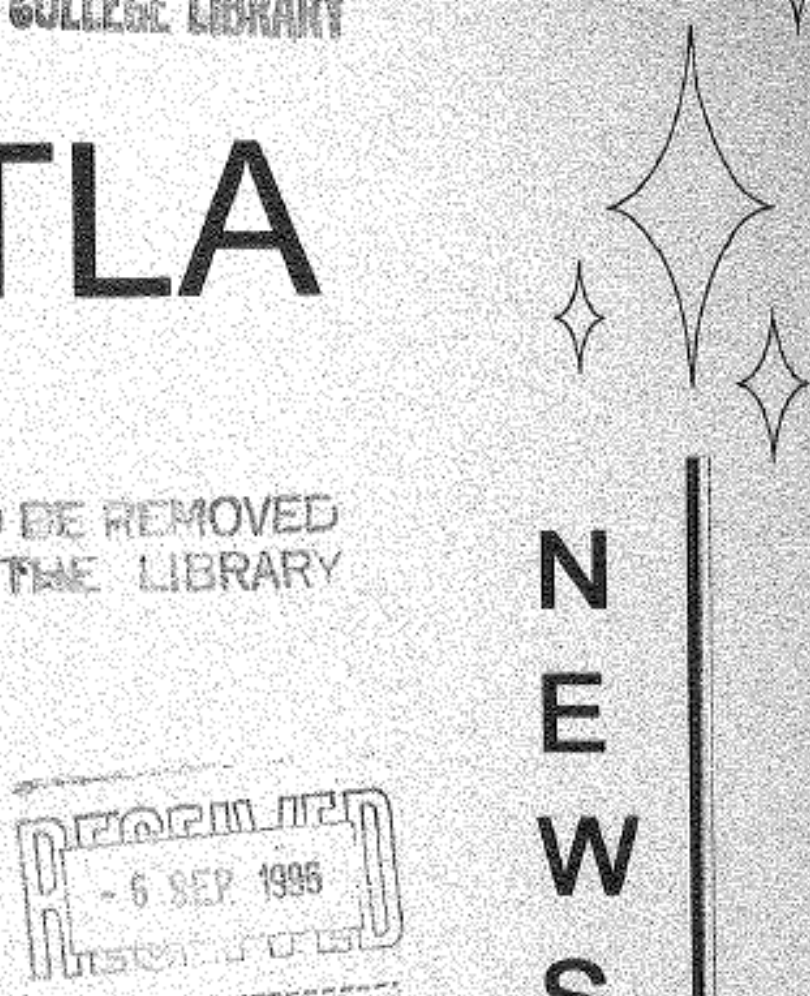

$\hat{\gamma}$
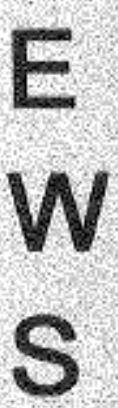

L

August 1996
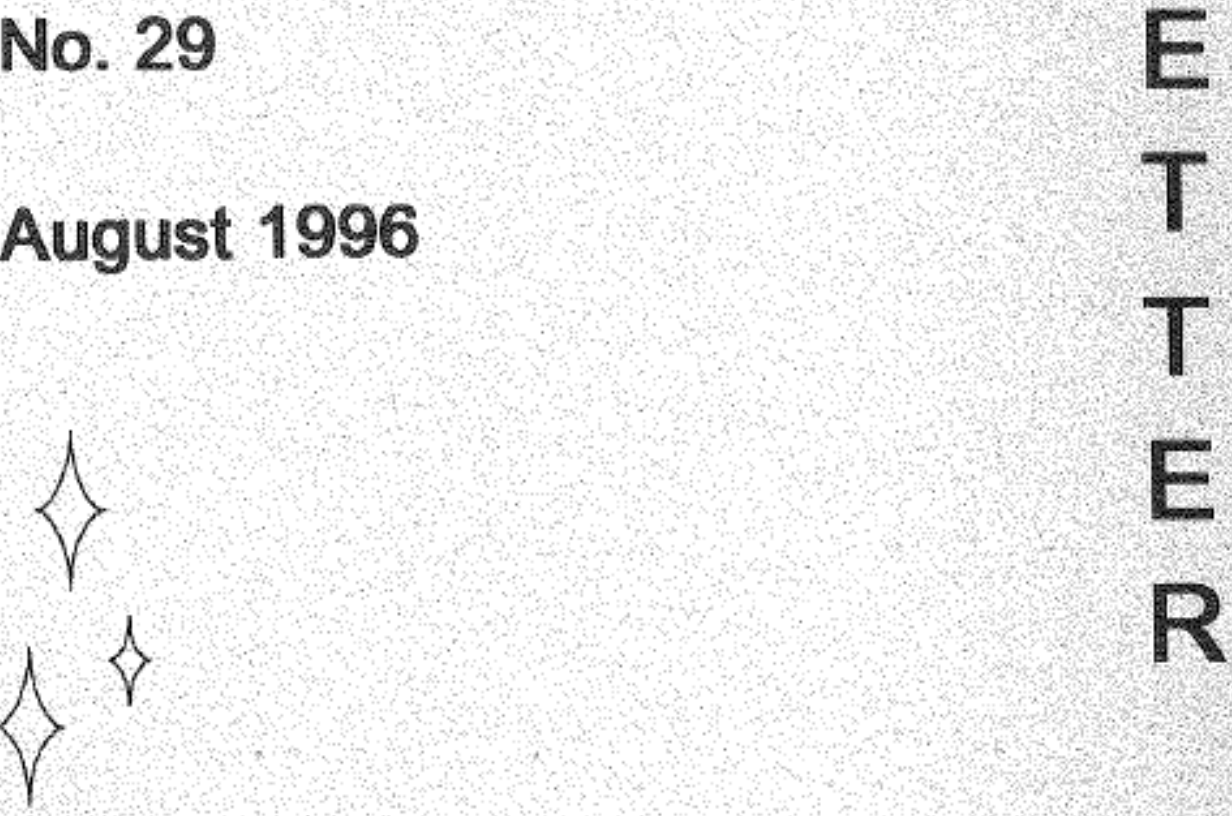


\section{ATSTRARINN AND NEW RWA AND THEOLOCHCAL LIBRARY ASSOCIATION}

AN7II:A is an association of librantes and individuals involved and interested in theological Hibranaiship. It seeks to co-operate with A ustralian and New Zealand Association of Theological Scthols and to promote its aims and objectives insofar as they apply to libraries and librarianship However, membership is open to all libraries and individuals sharing the interests of the Association, upon payment of the prescribed tee.

The ANZT1. A Newstetter is published three times a year to provide a means of communication between members and interested persons.

Confributions are nifvited of relevant articles and tems of interest to theological librarianship. soholaty artieles; information on all aspeets of librarianshp, book reviews, library profiles, and nevs about librines and librarians. Aftieles should be typed double spaced, and if submitted on disk. IBM or compatible in Word or AmPro is preferred Please send articles to the editor:

ANZWLA holds an ammual conference, in association with the conference of the Australian and New Lealand Association of Theological Schools where practicable Local chapters of the Association in the major cities provide a forum for local interaction

\section{ISSN $1030-701 X$}

President:

Trevor Zweck, futher Seminary

104 leficotl Streot, Nih Adelaide SA 5006

Fax 082672119

Secretary/T Teasurer:

Val Canty, Pakin Wesley College

20 King William street, Wayville SA 5034

Fax 083734874

Editor:

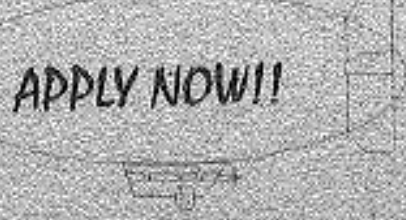

Executive Member

Lynn White, Baptist Theological College of WA

20 Hayman Rd, Bentley WA 6102

$\operatorname{Fax} 093621603$

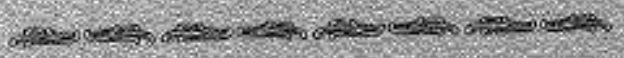

ANRTL A Vembership and Subscription to the Newsletter:

Association menbership tinc Newsletter subscription)

$\$ A 40 \mathrm{p}, \mathrm{a}$

Newsletter only

$\$ 420 \mathrm{pa}$.

Oversens surcharge

\$AS p.a.

Payment to Treasturer

Some back issurs avalable from the Iditor $(\$ 7.00$ each $)$ 


\section{Australian and New Zealand Theological \\ Library Association \\ Newsletter 29}

\section{CONTENTS}

From the Editor

The Internet and Users in Theological Libraries / Judith James

Yarra Theological Union Library / Margaret Lamb

From the ATLA Newsletter

Drawing the Lines on the Map: Types of Theological Libraries in Australia and New Zealand / Coralie Jenkin

Managing a One-person Library/Toni Silson

Automating for the Third Time/ Robert Knight \& John Scott

\section{From the Editor:}

Sadly, as this issue goes to press, the president of ANZTLA, Rev. Trevor Zweck, is unwell. His regular ANZTLA Affairs column would have told of his recent visit to speak at the ATLA Conference in the U.S. in July. I am sure that all members join me in wishing him a full recovery.

It was planned to have a list of members in this issue but as so many have not yet renewed their membership this will be in the December issue. If there is a renewal form in your issue of the Newsletter our records show you have not renewed. Please advise us if this is incorrect.

This is the last issue of the Newsietter to be published from Vianney College and I would like to thank all the people who have contributed, supported and given me feedback since I took on this task (especially the contributors). Thanks also to Judy James for her excellent support as Assistant Editor, and Janet Kemp, here in Wagga Wagga, for her technical support which has resulted in the new look of the News/eller.

I wish the new editor(s) well.

Irene Mills 


\section{ANZTLA NEWS}

\section{From Victoria:}

\section{Lawrence McIntosh receives Honerary Doctorate.}

At a ceremony on April 19, in the Wilson Hall, the University of Melbourne conferred the degree of Doctor of Sacred Theology (honoris causa) on Lawrence Mclntosh for his services to theological librarianship and theological education. The degree was awarded by the Melbourne College of Divinity, an ecumenical teaching and examining body established in 1910 .

Dr Brendan Byrne S.J. presented Lawrence for the degree, and, in the course of his address said:

He has exercised great leadership in the Australian and New Zealand Theological Library Association, displayed in conferences and most tangibly in the production of the Australasian religion index, which, as well as providing an invaluable research tool, has enhanced the awareness of librarians in other fields about the importance of theological scholarship in the advancement of knowedge. His major publication A style mamal (1994) is a splendid digest of information from a wide variety of sources. His many book reviews, bibliographical surveys and professional articles, as well as important unpublished reports on a number of theological libraries, have won him national recognition. His generosity in sharing expertise and information with younger and less experienced colleagues has made him greatly loved as well as academically respected in the library world.

flawrence has asked me to say, that in a wery real sense, he accepted this award on behalf of his colleagues in ANZTI.A, to whom he owes so much. - Ed.]

Coralie Jenkins has completed her P.D. thesis entitled Chamelling the gushing stream: theological libraries in Anstralia (the title comes from Proverbs 18:4 "The fountain of wisdom is a gushing stream", a reference to the vast amounts of material which flow into theological libraries and need to be properly channelled). Coralie was also granted a Publications Award by Monash University - this award includes funding for three months to write up her thesis for publication. She hopes to have two books published later this year; the first will be a history of eight theological libraries in Australia; the second, a biography of a nineteenth century librarian, Rev. Alexander Morison. She also plans to submit articles based on her thesis to journals, including this Newsietter.

- The first is in this issue - Ed.

From the Northern Territory

John Pinson has left his position as librarian at Nungalinga College.

From NSW:

A recent Chapter meeting was given a talk by Jerelynn Brown on writing Collection Development Policies. Jerelynn distributed a template of a CDP for small libraries produced by the ACLIS Collection Development Subcommittee which is reproduced here:

\section{NAME OF DEPARTMENT/LIBRARV COLLECTION DEVELOPMENT POLICY}

\section{Mission statement of the Department/Institution}

D. Quote directly from the most recent annual report. This section may include Key Results Areas, Strategic Directions or other core business statements. Why is it appropriate for the library to exist.

Other introductory material may be included here

\section{Clients}

1) Describe the clientele of the library including those potential clients which the service targets.

What drives these clients? Why do they need to use the library? Policy work, research, study, preparation of papers, talks and lectures, recreation.

The results of client research may be reported here if relevant.

Apart from primary client groups, what other clients may use the library?

Does the Department/Institution have a policy on who may use the library? 


\section{Statement about collection}

[ Is the policy to build a collection in specific areas or to provide a "just in time" approach? What is the view on accessing information vs. collecting it?

I If building a collection in certain areas, how are these identified? Does the library, for example, build to support Key Result Areas?

Do current events have any effect on the collecting policy?

Are multiple copics acquired? If so what is the guideline?

What is the level of client input to collection development: formal or informal input such as client council, suggestions for purchase, identifying necessary resources for core business/project work?

1] Are the publications of the Department/Institution archived in the Library?

- Include descriptions of major subject areas or features of the collection.

\section{Statement about relationship to other Departments/Institutions/libraries}

Are there other collections nearby or accessible electronically which mean this library need not hold certain categories of material? Are local collecting agreements in place, for example Sydney Subject Specialisation Scheme?

Does the library support the concept of the Distributed National Collection? If so what contribution can it make?

\section{Optional inclusions}

$\begin{array}{ll}\square & \text { Guidelines for collection review } \\ \square & \text { Controversial materials statement } \\ \square & \text { Freedom to read statement } \\ \square & \text { Censorship/bias statement } \\ \square & \text { Gifts and donations statement (including the right to dispose) }\end{array}$

\section{From the University of Newcastle, UK: \\ Customer Care Policy}

- We will put our users at the centre of our service

- We will create a service responsive to our users' needs

- We will treat our users with respect and courtesy

- We aim to provide a helpful and friendly service

- We wear name badges and will five our names to our users

We will provide the fullest possible service at all times within the constraints of available resources

- We are aware of and assist users with special needs; for example: part-time users, users with young children, users with disabilities and users whose first language is not English

- We publicise our service and opening hours and keep library users informed of changes

- We display library rules and regulations clcarly

- We provide customer care training for library staff

- We train our staff to provide a quality service

- We provide a suggestions book and comments forms, and undertake regular surveys of user opinion

- We reply to signed comments within one week

- We will use comments and suggestions to help us improve our service 


\title{
THE INTERNET AND USERS IN THEOLOGICAL LIBRARIES
}

\author{
Judith James
}

The Internet has spread its presence into all aspects of society, theological education included, with frightening speed, and we are swamped by information on the Internet. The ANZTLA newsletter has presented some excellent articles on various aspects of the Internet - from Trevis Lawton, Lynette Champion and others. My aim here is to gather my random thoughts and observations from a practical perspective which will, I hope, stimulate thinking about processes we engage in our respective libraries: the Internet and library users in the reference process, the implications of Internet access which librarians need to be aware of, and the issue of equity of access. 'User' here is taken to mean any library client, whether student, staff or member of the public.

The Internet is a dynamic research instrument which connects users to a global learning community, but it is also confusing for the new user, who can wander about in the maze, click and go to all sorts of places, which are often untested, have no structure, and in are a state of continual change. SURFING or searching by NET SEARCH or keyword is time-consuming. Our users, accustomed as they are to a well-ordered arrangement of information, such as they find on our library shelves, may expect similar order in an clectronic world. On our shelves resources are carefully selected to meet selection criteria, even hand-picked in these tough fiscal times, - but it's not like that in an electronic world. If's anarchy out there when it comes to standards and evaluation of information.

The technologically smart librarian can assist here by assuming a role as a 'filter and a finder' (Colin Steele's phrase $)^{1}$ : evaluating sites, checking their currency, bookmarking them, downloading them onto disc and passing on to staff or research students, setting up THEOLOGICAL HOT SPOTS to make the search process user-friendly to the new user.

Our role is no longer a GATEKEEPER of resources but a FINDER and FILTER.

More than ever there is a need for librarians to train users in information literacy skills such as locating resources, evaluating resources and recognising bias, so they will not be disadvantaged - or lost - in the maze of information on the Internet. At the point of need is the most effective method, but classes or training sessions are useful.

The reference process takes on a whole new meaning when we include the Internet - remember the key questions information studies textbooks teach to assist the user to clarify his/her enquiry? Well, these five questions, who? what? where? when? why? are spot on in shaping the Internet search strategy. The user's question can sometimes be answered quickly and simply by traditional means - by looking up a reference book. But younger students and users often think the secrets of the universe are found "on the Internet", and it is the librarian's role to discem the appropriate place to begin searching, often the Internet is the final place to look. Our role is to give the users the answer they need while engaging in some subtle user education, increasing their understanding of the range of available resources.

The user has access via the Internet to the most current information - for example: if a student or user is looking for the information on the latest on the intersection of science and religion, the $\mathrm{ABC}$ has a web site with news of programs on radio and television and links for further information. An aside here - have a look at http://www abc.net.au/m/relig/ for a great new packaging of the $\mathrm{ABC}$ religious programs - it is much more attractive than its print forerunner.

In 1996 we have seen the growth of excellent online sites for reference material - the net is becoming a 'one stop shop' especially for sociological material. MacquarieNet at http:/www.macnet.mq.edu.au gives access to a superb range of Australian material for the cost of several reference books * with a

, 
free three month trial. Another site is Finding God in Cyberspace ${ }^{2}$, written up in an ANZTLA newsletter in 1995 by Lynette Champion. This is a dependable, well-organised site and a great starting point for showing staff the treasures of the Internet.

Librarians have to decide if the scarce dollar will be spent on print or electronic resources, such as the above. While print media will continue to be a focus for research, expenditure will be increasingly diverted from information in print format to on-line services, - and the equipment to make those services available to more users.

The Internet indirectly provides advantages to the user when traditional library management tasks such as acquisitions and cataloguing can be done on-line. The user will have quicker access to new titles when libraries use on-line ordering. More suppliers are providing this service, along with previews of new titles: these include Blackwells, Blackwells North America, Uni-Coop, Ebsco, Scholar's Press. Some have a fee for the service - talk to the agency to negotiate a discount or waiving of the fee - theological libraries are renowned for their lack of cash. Cataloguers can consult the on-line catalogues of university libraries anywhere in the world for information for copy cataloguing.

One problem has surfaced which libraries who provide Internet access for students will have to resolve: with the availability of so much information on the net it is easy for users to copy, Alt+tab, paste, the information straight onto a word-processing document, which becomes the substance of the assignment or essay. Some students from school and university can be heard to comment: " there's nothing to writing assignments - it's so easy" without a thought of ownership of intellectual content. Lecturers and librarians need to be aware that this is likely to happen wherever there is Internet access. Plagiarism using the Internet is easier than photocopying. To prevent it requires careful planning when setting assignments so it is not "so easy", and also a continual program of user education by library staff, one-to-one, on the standards and guidelines for using the Internet in assignments.

We can make available an up-to-date set of rules for citing Internet sources to users, staff and students, but keep in mind that these guidelines are still evolving.

A reliable guide for religion and theology, although it does not yet have the Mcintosh customisation, is A Brief Citation Guide for Internet Sources found at <http:/hnet.msu.edu/ africa/citation.html > : It is derived from Kate L. Turabian, A Manual for Writers of Term Papers, Theses and Dissertations. With on-line information not only Intemet "addresses" or URL's have to be referenced, but any clectronic-mail correspondence or information from listservs or bulletin boards must also be cited correctly.

Access to the Internet and computer networks has generated a fresh wave of cooperation, as Al Hurd notes ${ }^{3}$. Our limited experience supports this - students, including theology students, receive useful responses from experts when they ask questions related to research on e-lists, listservs, or bulletin boards, for example, as found in Gresham's site, or on TELA for the Scholar's Press ${ }^{+}$. Do academics and experts answer letters from unknown undergraduates? Probably not, but they generously share their knowledge and resources in an electronic environment. The net is a democratic tool which gives all users, students and academics equal access to knowledge.

Therefore, our students and users are disadvantaged if they do not have access to the Internet. Theological libraries without access to host computers connecting them to the internet are as disadvantaged as residents who live outside the main cities when it comes to Internet access. Finances or their lack - are the problem for STD charges, computers and phone line charges. However, an Internet connection for theological libraries is a high priority. If there are no funds, seek out sponsorships - Telstra have funds for selected projects for telecommunications in education - lobby them to consider theological institutions. Seek out your nearest university and arrange Internet access,

It is found at $<\mathrm{http}-/ /$ users.ox.ac.uk/ mikef/durham/gresham, html $>$ until August 1996.

Hurd, Al. ANZTLA Newsletter No 28, May 1996. Pp5-6

<http://scholar.cc. emory,edu> 
in retum for a reciprocal service acceptable to them; information technology students sometimes need to develop home pages for course practical work, so giving your institution a presence on the internet.

The Internet collates, collects and disseminates information in a totally new way. Information which was previously obtained by visits, phone calls, or by asking librarians is now available 'up-front' to the user. Here I mean access via the Internet to library catalogues, university handbooks, course outlines and directories. A great democratisation of access to the resources of the National Library has taken phace, as Averil idwards at the Canberra ANZTLA Conference outlined to us. The resources of the National Library of Australia are now electronically available to the residents of Australia - not just those who live in the ACT. Visit the National Library Web Site' for a fantastic example of electronic resources, including the university and state library catalogues of Australia. Imagine finding out the location of works in reading lists, and whether they are available on the shelf without leaving home!

All of these information services give the user control and ownership of the research process. Processes which previously took time, or had to be done by others are now directly in the control of the user, with the added benefit of motivating the user by the interface with information.

However, in each of these processes the librarian is the essential link in connecting the Intemet to the user, at least for some of our users, and for those without access at home. Obtaining information from the chaos of the Internet becomes possible because sites are collated and available by bookmarks, instruction is available for searching the maze of the Internet and information literacy is taught as needed. There are many more issues which new technologies will force librarians to consider in the future, but the above are some which may come your way in 1996.

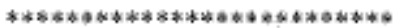

\title{
Yarra Theological Union Library.
}

\author{
Margaret Lamb
}

ANZTLA members will be saddened by the news of the demise of the Library of the Yarra Theological Union, one of the inaugural member libraries of the Victorian Chapter. The Library only, let me hasten to add; the Y.T.U. itself continues to flourish.

When the various Catholic religious orders cane together in 1971 to form the Yarra Theological Union, each order had its own fibrary to assist in the training and formation of their serninarians; some small, some larger. The YTU set up its lecture rooms and offices on the Franciscan property at Box Hill using St Paschal's library as its primary library resource centre. In 1982 the executive of the YTU decided to start a library collection of their own as a starting point should the Union move to another location.

Gwen Wilson was appointed Librarian and she remained in that position for thirtecn years until her retirement at the end of 1994, when she was succeeded by Judi Long who continued until her relocation to Sydney in 1995. Judi retains her connection to ANZTLA by continuing her M.Theol (begun at BCV) with Moore College.

Gwen was guided in the early stages by the Rev. Bill Goldsworthy and among her early helpers have been Janet Secomb and Coralie Jenkin. The Library grew into a "small but significant" (as Gwen referred to it) collection of books and journals numbering approximately 1200 monographs and 1500 joumal volumes concentrating on material for the courses given at YTU. Because of its proximity and larger collection of around 50,000 books, the main resource centre for the YTU courses and students remained St Paschal's Library. When Judi resigned last year the YTU executive requested the Paschal Province to have St Paschal's administer the YTU Library and to integrate its books and journals with St Paschal's holdings; the YTU would retain ownership and finance their collection. A similar integration was arranged some years ago with the Missiology section of the Divine Word Missionaries' library, in order to make it more readily available to YTU students. This arrangenent has proved quite satisfactory to all concerned, with the books involved now numbering in the vicinity of 900 . 
Over the Christmas break, the books and journals were moved across the passage to their new home and the YTU Library as such, was no more. It is now the YTU Book Collection held in St Paschal's Library. This collection is not static and will continue to grow. Should the future see the relocation of the Yarra Theological Union the books will be retrieved and the YTU Library live again!

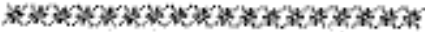

\section{From the ATLA Newsletter}

The Atla Newsletter has a regular column called "Diktuon". which covers items of interest about the Internet. The most recent one talks about searching the Web and is worth checking out if you thave any interest in this. I found it very uséful.

It covers several search services, but also introduces the reader to the reason why some strategies work better than others in searching the Net. Here is an extract from it:

\begin{abstract}
"Relevant" Strategies
It should be clear that using a relevance engine requires a somewhat different strategy than a traditional Boolean search engine. Of course, you still want to use the most specific and accurate terms you can identify. It still really helps to be familiar with the subject, the characteristics of the database. and the particular search engine you're using. Tut with relevance engines, more is better. Basicaily you want to buid up a context for your query that will allow software to score results more effectively. For example, if you are looking for sites dealing with the ordination of women in the Roman Catholic Church you might enter something like this:
\end{abstract}

ordination ordain women woman Catholic Roman priest churcb clergy female sh.

(Hardly how you'd advise someone to search the local OPAC) it's unlikely that all those terms are going to appear in any one hit, but it's also clear that sites with a high percentage of those terms are likely to be relevant.

Interestingly enough the Boolean "NOT" operator, which is rarely used in traditional keyword searching can be very helpful when working with relevance engines if it is supported....

Check out the Newsletter yourself on http://atla. ibrary vanderbilt edu/atia/

\section{Western Anstralia in October is a Remarkable Place!!}

Not only is the ANZTLA Tradition and Technology Conference being held in Perth from the 10-13th, but this is the time the country is transformed by a camet of flowers to a beauty that is hard to imagine and even harder to describe.

This year you have the chance to use the ANZTLA conference as an excuse to see this. Good winter rains should make this year's display a spectacular one and the scheduled visit to New Norcia, the historic Spanish Benedictine settlement, will give those with no extra time for sightseeing the opportunity to have a taste of it.

As well as sightseeing a program to cater for libranes both large and small; advanced and advancing, and librarians leamed and learning has been plarned. For more information and enroment contact Lymn White (ph):09 3619962; fax: 09362 1603). 


\section{Drawing the lines on the map: Types of theological libraries in Australia and New Zealand}

Coralie Jenkin

Preface

In recent years there has been a steady growth in the number and diversity of theological libraries existing in Australia and New Zealand. The use of the term 'theological library' without indicating the fype of library has given rise to problems for those people who wish to define, describe or compare theological libraries. In this article I have created three major calegories of theological tibraries, and also discursed theological collections in other libraries. The article is faken from the second chapter of my doctoral thesis, and I am grateful to Monash Unisersity for providing funds throngh the Publications A ward to write up my thesis for publication.

A thicological library can be defined as one which principally collects works of theology, the three major categories of theolngical library in Australia are academic (the libraries of theological colleges), monastic (those which serve religious communities), and resource centres (for lay people). Some fibraries fall into more than one of these categories - for example, a monastic library which is housect in a institution where theology is taught. These categories detine libraries by types of users, not by materials heid - there is some relationship between user and coliection, but this relationship is sometimes blutred, especially in the case of the second category, monastic libraries.

Academic theological libraries provide materials for students, most of whom are undergraduates. These libraries cisitily a aise provide materiais for the coilege's academic staff and for ministers from the sponsoring church/churches, as well as for post-graduate students, researchers, and in some cases, members of the public. Most of these colleges are denominationally based, but some, such as Bible colleges, are non-denominational. The collections in academic theological libraries consist mainly of materials for college programs, including reference works and some non-book materials, as well as research-level materials in selected areas. The size of these libraries varies considerably, ranging from Moore College (Newtown, NSW) with 115,000 volumes ${ }^{6}$, and the Joint Theological Library (Parkville Vic), with 112,000 volumes, the two largest collections of theology in Australia, to the Norman Dunning Library of the Pacific College for Evangelism (Nth Parramatta NSW) which holds only 200 volumes. Although libraries in this category have been established to serve one type of user they may be extensively used by other groups. For example the Lohe Memorial Library, Luther Scminary has more members of the public than theological students on its register of borrowers. This situation is partly explained by its collections of materials for ministers and teachers which are made available to the public.

The second category is monastic libraries - the libraries of monastic communitics - most of which belong to the Roman Catholic Church, althongh the term 'monastic' is not meant to imply that the library is located in a monastery. These libraries are usually small, holding collections which specialise in doctrinal, devotional and popular works of theology and the history of the supporting body. Many monastic libraries are not open to the public, although members of the public may be permitted to use the collection by arrangement. Examples of libraries in this category are the libraries of Assumption Seminary, Plumpton, NSW, which holds 10,000 volumes and the Augustinian Pre-Novitiate House in Brookvale, NSW which holds 200 volumes. Both of these libraries belong to the Roman Catholic communities ad may be used by members off the public only by arrangement with the librarian. Monastic libraries which hold notable collections of theological materials include St Dominic's Studium Library, St Dominic's Priory (Camberwell, Vic), which holds 40,000 volumes and the Holy Trinity Abbey Library, Benedictine Community (New Norcia, WA), which holds 25,000 volumes. Because they are held within a community - resembling personal rather than public collections - and their owners do not want the library's existence publicised, many monastic libraries are not listed in Collections of religion and theology in Ausiralia and New Zealand (CORT) or other library directories.

The boundaries of these categories become blurred when monastic libraries also serve as academic theological libraries or resource centres. Monastic libraries which are also academic theological libraries are those which are used by students who are community members. These libraries are likely to have collections which have more in common with academic theological libraries than other monastic libraries. An example is the Veech Library, Catholic Institute of Sydney, which in earlier times was used only be students and staff of St Patrick's College. When the college was opened to people outside the community, the Veech library was opened to non-resident students, but it still serves St Patrick's College residents at the Catholiv Institute of Sydney. ${ }^{3}$ All statistics in this article are taken from Jenkin, Coralie E.J. Collections of religion and theology in Australia and New Zealand. Adelaide Auslib Press, 1992.

This example was given when the Catholic Institute of Sydney was at Manly. 
The second area in which the categories are blurred is that of monastic libraries which are also resource centres: those libraries which hold collections of theology, are located in a community, and provide a resource for people outside the community. An example is the Shalom Library at the Centre for Christian-Jewish Relations (Kew, Vic), which has a collection of 2,000 volumes. The Centre supported by the Roman Catholic Church, aims to foster relationships between Christians and Jews by providing materials to members of the public in the field of Judaica and Christian/Jewish relations.

Libraries in the third category, resource centres, collect materials principally for lay members of the sponsoring church or for a particular interest group. These libraries usually concentrate on collecting materials with a practical rather than an acadenic focus. Examples include the Catholic Education Offices (Adelaide, Townsville, Cairns, Leichhardt, Canberra and Melbourne), which collect materials for religious education teachers. Resource centres range in size from the Central Catholic Library (Melbourne), which holds 55,000 volumes, to the smallest theological libraries, such as the Australian Student Christian Movement Library at the University of Melbourne, which holds only 200 volumes. Resource centres are usually smaller than libraries in the other two categories, holding, on average, about 750 volumes, although it is very likely that if all monastic libraries were to be included in a count, there average size would be smaller. Some resource centres listed in CORT are so small that it is likely that they have additional collections of non-theological materials. Many of the resource centres have been created relatively recently, and they have yet to build up their collections.

These are the major types of theological libraries, but at least a few theological works can usually be found in all libraries in Australia, ranging from a large collection in an academic library to perhaps just a Bible to be used for legal purposes or books of theological reflections in a library with a main subject emphasis elsewhere. This universality can be attributed to Australia's religious heritage, to the use of scripture for legal and reference purposes, and to the scope of theological subject matter:

Religion appears to pervade all aspects of individual experience and ways of knowing, and impinge, in some measure or other, on all areas of human endeavour and achievement (Osborne, $1978,7)$

Academic libraries in Australia hold varying amounts of theology, depending on such factors as courses which are being, or have been taught, separate collections, donations and archival holdings and on whether the university is associated with a religious body. These holdings are increasing following the recent establishment of church-supported universities, affiliation agreements with theological colleges, and an increase in the number of subjects in theology being offered by secular universities - movements which have taken place mainly since the beginning of the $1980 \mathrm{~s}$. The older universities and those more recent ones which teach theology have larger collections - the largest colfection of theology in a university library in Australia is held at Fisher Library in the University of Sydney, which in a collection of 4.2 million items has 46,000 items in theology, including the archive of Australian Judaica. This figure ranks the University eleventh in size of theological collections in Australia, the largest collection held by a secular body and a collection larger than the collections of many theological libraries. None of the 'universities of technology' - developed in Australia since the 1980s completed the CORT questionnaire; those which were contacted by telephone did not want to be included in the survey because their libraries held so little theology.

There are some collections of theology held in university college libraries sponsored by churches. An example is the Jeremiah Murphy Library, Newman College, University of Melbourne (Parkville, Vic), which holds 2,260 volumes of theology in its collection. Some libraries located in university colleges are also the libraries for theological colleges, which means that they have collections both for theological students and for university students. An example is the Leon Morris Library of Ridley College (Parkville, Vic), which has a collection of 36,000 volumes.

There are a few special libraries not supported by a religious body which hold collections of theological materials. These are libraries which specialize in subjects to which theology makes a contribution. Examples include the Gibraries of Action for World Development (Surry Hills, NSW) and the Summer Institute of Linguistics (Berrimah, NT). Many other special libraries hold theological materials peripheral to their subject - for example libraries in the fields of history, language studies, sociology and psychology, while the contents of archives often reflect the large volume of theology generated in the past.

The state librarics all hold collections of theology - for example the State Library of Queensland has a collection of 17,000 volumes, including collections of hymnology, folk hymns and music. Many of the works in the state library collections date from the 19th century, reflecting the emphasis on religion at that time, the output of theological publishing, and the role of ministers in the governing bodies of the state libraries. The National 
Library of Australia holds a collection of approximately 20,000 volumes of theology. The library contains extensive collections of missionary records in microform... a high collection level in the following subjects: religion, religions, theology, social and ecclesiastical theology, church history, sects, comparative religion, Indian religions, Judaism, Islam'. Approximately 3,000 volumes donated to the National Library from the Austalian Buddhist Libiary, which, with the National Library's other holdings of Buddhist literature (Gosling, 1995), forms
the largest collection of Buddhist works in Australia.

Although public libraries hold a few volumes of theology - usually popular, donated and reference works $\sim$ a small number hold genuine collections of theology. Other libraries which may hold collections of theology include school libraries: those which do not have a religious affiliation ustally hold copies of the scriptures and theological reference works, while those with religious affiliation can be expected to hold materials about their own church as well as resources for religious education and devotional reading. Many churches own small tibraries for their mernbers or for children in their Sunday Schools.

\title{
Biblingraphy:
}

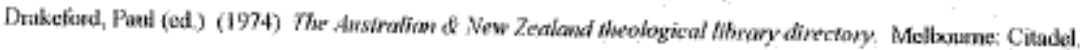

Jenkin, Coralie E.J. (od.) (1992; Collections of religion cand dheology in Awstrofiza and New Zeakand. Adelaide: Auslib Press.

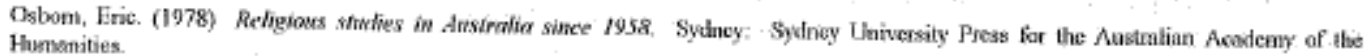

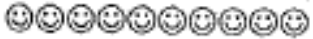

\section{Managing a One-person Library \\ Toni Silson, Lady Davidson Hospital}

\author{
Reproduced with permission. First published in InCite May 1996, p.15
}

The most important point to remember in managing a one-person library is that you, as the librarian, are really managing yourself. The aspects of management that you need to be aware of, therefore, are the importance of time management and setting priorities, planning the service ethic, and networking.

\begin{abstract}
Time management
Because of the limitations inherent in managing a one-person library, being able to manage your time effectively is of primary importance. It is necessary to be realistic in your appraisal of the amount of time taken to do specific tasks, and of the importance of each task to the overall objectives of the library. You will therefore have a clearer idea of which services are necessary, and which are just 'nice', and allocate your time accordingly.
\end{abstract}

The limitations of a small library are not necessarily a cause for apology. It is possible to do a particular job better than larger libraries, whose resources and services are less focused. The staff and management of the organisation which the library serves should also be aware of the limitations

inherent in a small but specialised service. There should be no feeling of disappointment, either in them or the librarian, if it becomes necessary to refer them on to another type of library or service. Many one-person libraries are also staffed by part-time librarians. This makes time management and prioritisation even more difficult. There is often a feeling of guilt on the part of the librarian that s/he is not able to provide all the services that s/he (or the users) would like. Although this feeling is natural, it is not necessary, as these limitations are imposed by the organisation, not the librarian.

\section{Planning}

Time put into planning and setting objectives is not wasted time, as without objectives, it is not possible to adequately prioritise work. Many one-person librarians complain about the lack of time to do everything that needs to be done. This is often true, but it is also true that time will be found when the work is considered necessary to the good management of the library; and planning is as necessary as shelving books. 


\section{Service ethic}

When planning it is most important to remember that the libary's raison d'etre is to provide a service to its particular clientele. It is often necessary for a librarian in a one-person library to do as mach boring and mundane work as there is challenging and interesting work. However, if that is what it takes to provide a good service to your users, then it is important work, and worthy of your best efforts: what is the good of a wonderful collection if it is shelved so badly that no-one can find anything?

A librarian in a one-person library must be prepared to do a little, a lot. However, the variety of tasks is often a compensation for the lack of time spent on each. Although it is often not possible to spend the amount of time some people would like in order to catalogue an item 'to perfection', there is also satisfaction to be found in doing acquisitions, cataloguing, processing and circulation all in the one afternoon!

\section{Networking}

Being the only one of your kind in an organisation can often lead to a fecling of isolation and professional or personal stagnation. It is most important to overcome this by professional development (including attending conferences, meetings and seminars) and networking, both within the organisation and with other librarians in a similar situation.

'Management by walking around' is a very useful method of getting yourself (and therefore your library) known around the organisation, and also of discovering how you can best serve your current, or prospective clients; use their

suggestions or critiques to help improve your services.

Professional networking is essential to the manager of a one-person library in order to keep up-to-date on changes in the profession (especiaily in relation to technology) and also to gain the sort of support only possible from those who are in the same situation. A new special interest group. OPAL (One-Person Australian Librarians) has recently been formed to help in this regard. The purpose of this group is to act as a national forum to discuss topical issues, provide support, share problems and solutions and exchange ideas unique to library professionals working in one-person libraries. It is intended that it will be for librarians in a wide range of libraries, from hospital and special libraries, to schoof libraries, and small public or TAFE libraries, to name a few. It will provide foruns for discussion via a newsletter, meetings, library visits and hopefully, via the Internet. Those interested in joining the group should contact Georgina Dale, Janssen Cilag, Locked Bag 30, PO, Lane Cove 2066. Telephone (02) 779 2364, Mobile 0416019271 . Fax (02) 7792399.

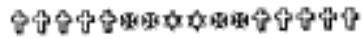

\section{NEW BOOKS:}

Martin, Lynne M. (ed.) Library instruction revisited: bibliographic instruction comes of age. Binghampton, N.Y.: Haworth Press, 1995. ISBN 1560247592 Price: US\$59.95

This book of essays is worth reading if you conduct any reading education program in your library. Also published as The Reference Librarian numbers 51/52, 1995, it includes a look at the development of reader education/bibliographic instruction, learning theories, teaching technology and teaching with technology, and a look at RE for diverse cultures. The aspects of this book I found most interesting was that dealing with technology, especially the Internet, and also RE targeted at students from other cultures. As with most issues of The Reference Librarian there is a strong emphasis on practical aspects and the experience of other libraries/librarians. Having read this book, I was encouraged to take a fresh look at my own practices, and think about the expected outcomes of my reader education programs and whether I was achieving these.

Another interesting book I have come across recently is:

Thomasen, Elizabeth. Reference and collection development on the Internet. New York: Neal-Schuman, 1996. ISBN: 1555702430.

The title of this book sounds very promising and it is one of the A how-to-do-it mamal for librarians series. many of which are very useful. While I found the collection development section a little disappointing (although it would be of more use to a generalist library) reading this title belps overcome the feeling of touching the edges 
of chaos that sometimes comes with using the Internet. The author allows the librarian to constructively approach the vast quantities of information that are on the Internet. Her aim is to give librarians "a sense of the Intemet as a community of individuats and organizations who share information through online conversations and online resources:" (p.xi) To do this she covers the use of e-mail, newsgroups and Frequently Asked Questions, as well as library catalogues, databases and electronic books in reference and collection development work. While the lists of Web sources in the appendices are most sâitable for public libraries (and some appear to no longer exist), there are useful strategies and principles here for the library professional, particularly those working in customer service areas. This book can only help boost any librarian's confidence, especially the more inexperienced Internet user, when approaching this rathes daunting information resource.
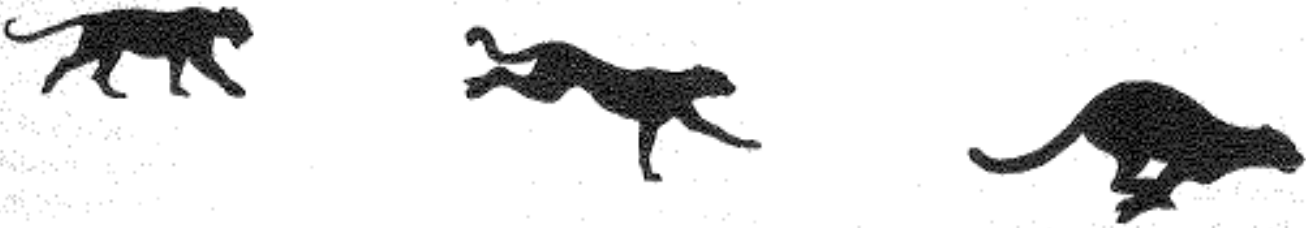

In July the Riverina Regional Library Service lannched a wew Library system. This was the worldwide launch of the very attractive windows-based Libero system from Insight in Queensland. The following short article describes the process of getting to this stage. Altholgh this system is in a public library, the experience described here would be of interest to anyone dealing with branch libraries.

\title{
AUTOMATING FOR THE THIRD TIME
}

\author{
Robert Knight \\ John Scott
}

During the carly part of 1994 , it was becoming increasingly obvious to senior management at the Riverina Regional Library that the existing automated library management system was not catering to our needs, particularly in the area of service provision to our temote branches. The regional library includes a total of 10 branches within a $100 \mathrm{~km}$ radius of the central library at Wagga Wagga, nine of which are not within local call access. The existing computer system did not facilitate the delivery of a number of basic library services at branch level, such as book reservation, member registration, automated catalogue facilities, and OPAC access. All work associated with these processes had to be done manually at headquarters, using either fax or phone to communicate messages; far from an efficient or cost effective means of doing business!

Consideration was given to installing direct lines at branch libraries, but costs ruled this option out and at the time our existing vendor was unable to provide an appropriate software solution. The quality and philosophy surrounding the telecommunications infrastructure in rural Australia leaves country residents seriously disadvantaged in terms of access to technology in situations such as these.

The decision was subsequently made to apply for a Library Development Grant in the annual NSW Library Council grant process to assist us in funding a computer system which would fulfil the immediate and future nceds of the Riverina Regional Library. Early in May 1995 confirmation was received of a grant allocation of $\$ 80,000$; this amount, combined with library funds, enabled us to take the first steps towards purchasing a computer system which would meet our specifications. Earlier research had revealed that few software vendors currently had products available that would meet all of our remote branch requirements, without compromising the considerable functionality that our existing system provided at the central library, so we proceeded to write a very detailed tender specification document for our specific site requirements. Thankfully, we were able to use the excellent document prepared some months earlier by Richard Nichols of Clarence Regional Library as the basis for a very comprehensive and detailed specification.

We aftempted to document all of our requirements in almost agonising detail, recognising that anything not included may well be omitted from the end product, and the vendor could argue "it was not in the tender document". 
Some 30 tender documents were requested in response to advertisements placed in national papers, after which we waited (impatiently) to see what products and prices would be offered to us.

The day eventually arrived when the responses were opened, and from an initial field of 8 , we very quickly identified three systems which had the potential to fulfil our many requirements. Vendor presentations were scheduled, and after detailed presentations in which strategic staff were involved, the choice was narrowed down to two vendors. After considerable deliberation, including visits to existing sites at which each product was operational, the decision was made to select Insight Informatics, offering a new windows-based product which was in the final stages of development from the existing character based system. Several factors influenced our final decision:

D] Insight guaranteed that we would have extensive input into the software development process, ensuring that the end product would be tailored to the requirements of our site in as far as practical

[) Insight's existing user base was specifically public libraries in NSW, and the company demonstrated a very clear understanding of the needs of country public libraries

Existing Insight sites which were either visited or contacted spoke highly of the quality of the product and the support offered by the staff.

In December 1995 the development process began with the arrival of Sam Patane, the CEO from Insight Informatics in Brisbane, just two days after we notified him! A test system was set up on a stand alone PC with the skeleton of the new. Windows system loaded. January 1996 saw a test data outload begin, which was sent to Brisbane for analysis.

The tibrary system had made the decision to concurrently upgrade computer hardware throughout all branch libraries, and expressions of interest for the supply of hardware were sought in early February. The quotation from Total Peripherals Group (Wagga Wagga) was successful because of its competitive edge in price, availability of local support, and a three year parts and labour warranty which was significantly greater than other offers.

A variety of factors contributed to a less than ideal experience with data conversion; there was a distinct lack of information available about the structure of data held on the existing system, which did not make the task easy. Libraries do, at times, decide to move to different software platforms because of changing needs, and vendors need to recognisc this as part and parcel of the nature of technology; whilst vendors cannot be expected to reveal proprictary information, the process need not be as difficult as ours proved to be.

The Insight Libero Windows-based library management system has, at the time of writing this article, been operational at the Wagga Wagga City Library for one week, preparatory to its staged introduction to the remainder of our branch libraries. This is the first time that the system has been installed anywhere in the world; it is currently being demonstrated in Europe and Asia, and is the subject of strong reviews and a great deal of interest. We believe that the product has matured significantly over the duration of our involvement, and will continue to grow and develop in the coming twelve months.

Robert Knight is Director of the Riverina Regional Library and John Scon Regional Services Librarian.

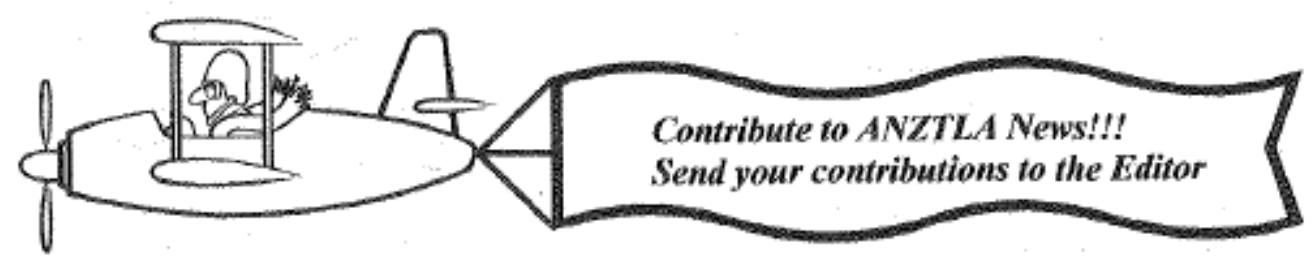




\section{A Selection of Available Titles in Asian Theologies}

R \& J England

\section{China, Hong Kong}

Chaves, J. Singing of the source: nature and god in the postry of the Chinese painter Wu Li. Honolulu: Univ of Hawaii Press, 1993.

Kwok Pui Lan. Chinese women and Christianity 1860-1977. Atlanta: Scholars Press, 1992.

Kwok Pui Lan. Discovering the Bible in the non-biblical world. Maryknoll, N.Y.: Orbis Bks, 1995

Tang, P. \& Wiest, J-P (eds) The Catholic Church in modern China: perspectives. Maryknoll, N.Y.: Orbis Bks, 1993.

$\mathrm{Yu}, \mathrm{C} . \mathrm{T}$. Being and relation: a theological critique of Western dualism and individualism. Edinburgh: Scottish Academic Press, 1988.

India

Massey, J. (ed.) Indigenous peoples; Dalits: Dalit isstres in today's theological debafe. Debli: I.S.P.C.K, 1994

Samartha, S.J. One Christ, many religions: towards a revised Christology. Maryknoll, N.X.: Orbis Bks, 1991. [sec also Klootwijk, E. I Commitment and openness: the imterreligious dialogere and theology of religions in the work of Stanley Samartha. Zootemeer, Uitgeverij: Boekencentrum, 1992.]

Sugirtharajah, R.S. \& Hargreaves, C. Readings in Indian Christian theology, I: the way and the word London: S.P.C.K., 1992.

Sumitra, S. Christian theology from an indian perspective. Bangatore: Theological Bk Trust, 1990 .

\section{Indonesia}

Darmaputera, E. Pancasila and the search for identity and modernity in Indonesian Society: a cultural and ethical analysis. Leiden: Brill, 1988.

Hardawiryana, R. [et al.] Building the church in pluricultural Asia. Rome: Centre for Cultures and Religions, Pontifical Gregorian University, 1986.

Partonardi, S. S. Sadrach's community and its confextual roots: a toth century davanese expression of (hristianity. Amsterdam. Rodopi, 1988

Rae, S. Breath becomes the wind: old and new in Karo religion. Dunedin: Univ, of Otago, 1994.

Sumartana, Th. Mission at the crossroads: indigenons churches, limropean mixsionaries, Istamic association and socio-religions change in Java 18/2-1936. Jakarta: BPK Gunung Mulia, 1993.
Japan

Habito, R.L.F. Total liberation: Zen spirituality and the social dimension. Tokyo; Maryknoll, N.Y.: Sophia University; Orbis Bks, 1988.

Habito, R.L.F, Healing breath: Zen spirituality for a wounded earth. Maryknoll, N.Y.: Orbis Bks, 1993.

Kinukawa, H. Women and Jesus in Mark: a Japanese feminist perspective. Maryknoll, N.Y.: Orbis Bks, 1994.

Kitagawa, J,M. The quest for human unity: a religious history. Inneapolis: Fortress, 1990. [see also Kitagawa. Spiritual liberation and human freedom in contemporary Asia. New York: Peter l.ang, 1990.]

Kumuzawa, Y, \& Swain, D.L. (eds) I. Christianity in Japan, 1971-90. Tokyo; New York: Kyo Bun Kwan; Friendship Press, 1990.

Reid, D. Religious change in Japan: the cultural shaping of Japanese Christiamify, Berkley: Asian Humanities Press, 1991. (Nanzan studies in Asian religions; 2)

\section{Korea}

Chung, H,K. Siruggle to be the sun again: introducing Asian women's theology. Maryknoll, N.y.: Orbis Bks, 1990.

Kim Yong Bock. Messiah and Minjung: Christ's solidarity with the people for a new life. Hong Kong: Christian Conference of Asia, 1992.

Leo Jae-Hoon. The exploration of the inmer wounds: Han. Atlanta: Scholars' Pr., 1994. (AAR series; 86)

Lee Jung Young (ed.) An emerging theology in world perspective: conmentary of Korean Minjung theology. Mystic, CT: Twenty-Third Pubs, 1988.

Suh Kwang-Sun, D. The Korean Minjung in Christ. Hong Kong: Commission on Theological Concerns, Christian Conference of Asia, 1991.

\section{Mainland South-East Asia}

Batumalai Sadayandy. An introduction to Asian theology: an Asian story from a Malaysian eye for Asian neibonrology. Kuala Lumpur: Seminari Theologi Malaysia, 1988.

Hunt, R., Lee Kam Hing \& Roxborough, J. (eds) Chrisfianity in Malaysia: a denominational history. Petaling Jaya: Pelanduk Pubs, 1992.

Roxborough, J. A common voice; a history of the ecumenical movement in Malaysia. Kuala Lumpur: Council of Churches in Malaysia, 1991.

Sivaraska, S. A socially engaged Buddhism. Bangkok: Thai Inter-Religious Commission for Development, 1988.

Yap, Kim Hao. Doing theology in a pluralist world. Singapore: Methodist Bk Room, 1990. (10 Mount Sophia, Singapore 0922) 
Hamlin, J. God, builder of seciety: the imporiance of the Old Tesiament prophets for the Southeast Asian church. Bangkok: Suriyaban Pubs, 1992.

\section{Pakistan}

Nazir-Ali, M. From everywhere to everywhere: $a$ world view of Christian witness. London: Collins, 1991.

\section{Philippines}

Aviso, N.S. [et al]. Philippine society: reflections on contemporary issues. Quezon City: Institute of Religion and Culture, 1990 (Kalinangan book series; I)

Aviso, N.S. [et al]. Currents in Philippine theology. Quezon City: Institute of Religion and Culture, 1992. (Kalinangan book series; II)

Gallares, J. Images of faith: spirifuality of women in the Old Testament. Maryknoll, N.Y.: Orbis Bks, 1992.

Kiley, H.W. (ad.) Filipino tribal religions experience. Quezon City: Giraffe Bks, 1994. (Biblical and non-Biblical revelation series; no. 2)

Mercado, L.M. (ed.) Filipino religions experience and non-Biblicat revelation. Manila: Divine Word Pubs, 1992.

Mercado, L.M. Inculturation and Filipino theology. Manila: Divine Word Pubs, 1992.

\section{Sri Lanka}

Ariaraja, S.W. Hindus and Christians; a century of Protestant ecumenical thought. Amsterdam; Grand Rapids, Mich.: Editions Rodopi; Eerdmans, 1991.

Ariaraja, S.W. Gospel and culture: an ongoing discussion within the ecumenical movement. Geneva: W.C.C., 1994.

Balasuriya, T. Right relationships: de-routing and re-routing of Christian theology. Colombo: Centre for Society and Religion, 1991. (Logos; $30,3 \& 4)$

Dornberg, U. Searching through the crisis: Christians, contextial theology and social change in the 1970s and 1980s. Colombo: 1992 (special double issue of $\log o s ; 31,3$ \& 4)

Pieris, A. Lowe meets wisdom: a Christian experience of Buddhism. Maryknoll, N.Y.: Orbis Bks, 1989.
Taiwan

Song, Choan Seng. Jesus and the reigh of God Minneapolis: Fortress Pr., 1993.

Song. Choan Seng. Jesus in the power of the Spirit. Minneapolis: Fortress Pr., 1994.

Song, Choan Seng. Jesws the crucified people. New York: Crossroad, 1990. (The cross in the lotus worid; v. 1).

\section{Regional}

Abraham, H.C. (ed.) Spirimality of the Third World: a cry for life. Maryknoll, N.Y.: Orbis Bks, 1994.

Abraham, K.C. (ed.) Third world theologies: Maryknoll, N.Y.: Orbis Bks, 1990.

Devanandan, F.T. \& Balasudaram, F.J. (eds). Asian expressions of Christian commitment: a reader in Asian theology. Madras. Christian Literature Society, 1992

Eppsteiner, $\mathbb{R}$. (ed.) The path of compassion: wrilings on sacially engaged Buddhism. Berkeley Parallax Press, 1988.

Fabella, V., Lee, P. \& Suh, D. Kwang-Sun (eds). Asian Christian spiritwality: reclaiming traditions. Maryknoll, N.Y., Orbis Bks, 1992.

Hefher, R.W. (ed.) Comersion to Christianity: historical and anthropological perspectives on a great transformation. Berkeley: Univ. of California, 1993.

King, U. (ed.) Feminist theology from the Third World: a reader, London; Maryknoll, N.Y.: S.P.C.K.; Orbis Bks, 1994.

Le Febure, L.D. The Buddha and the Christ explorations in Buddhist and Christian dialogwe. Maryknoll, N.Y: Orbis Bks, 1993. (Faith meets faith series0)

Sugirtharajah, R.S. (ed.) Asian faces of kesws. Maryknoll, N.Y.: Orbis Bks, 1993.

Sugirtharajah, R.S. (ed.) Frontiers in Asian Christian theology. Maryknoll, N.Y.: Orbis Bks, 1994.

Sugirtharajah, R.S. (ed.) Voices from the margin: interpreting the Bible in the Third World. London: S.P.C.K, 1990.

Prepared by Rita and John England, Chrisichurch NZ, for Canterbury Uniwersily Library

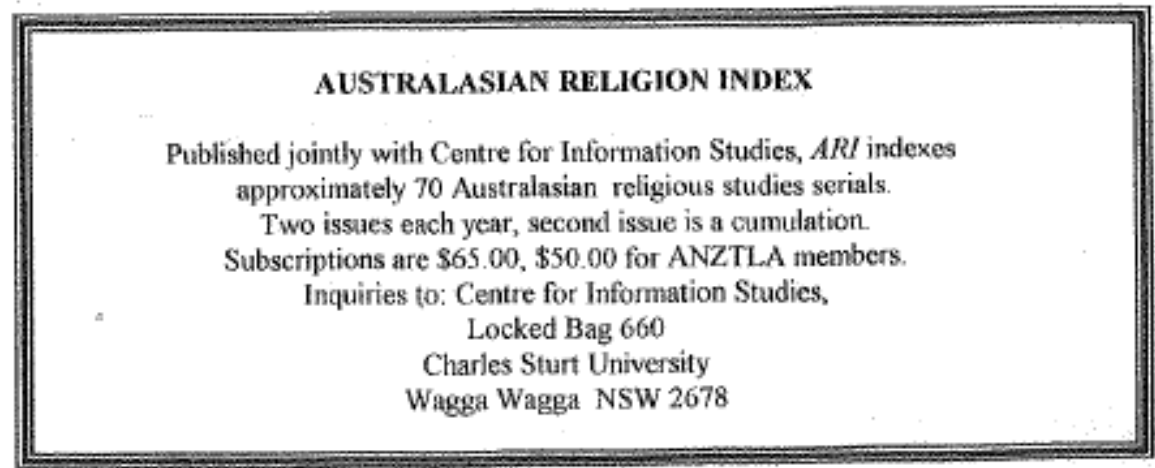




\title{
Forthcoming Publication:
}

Religion and theology: a guide to current reference resources by Lawrence $D$. Mcintosh Wagga Wagga: Centre for Information Studies, 1996.

This guide is designed to introduce students, teacher's, librarians and others to current reference resources in the fields of religion, religions and theology. It covers general reference resources and subject reference resources.

Subjects covered include:

\author{
religions in the world \\ Judaism \\ Christianity - church history \\ Christianity - the churches in the world \\ the Bible and related literature \\ Christian theology \\ Christian worship. Liturgy, preaching, church music \\ spirituality \\ religious and theological education \\ religious art and music \\ pastoral care and counselling \\ philosophy and ethics \\ religious and theological periodicals
}

Lawrence McIntosh, BA, BD (Hons), MS (Hons), PhD, AALIA, retired last year as Librarian of the Joint Theological Library in Melbourne. He has taught research methodology and theological bibliography both in the United States and Australia. He is author of A style mannal for the presentution of papers and theses in religion and theology, also published by the Centre for Information Studies, 1994.

Order enquiries should be addressed to: Centre for Information Studies, Locked Bag 660, Wagga Wagga NSW 2678. PH: 069 332325; FAX: 069 332733; EMALL cis@csu.edu.au

\section{CHAPTERS UPDATE}

\begin{tabular}{|c|c|c|}
\hline NSW Chapter: & $\begin{array}{l}\text { President } \\
\text { Secretary/Treasurer }\end{array}$ & $\begin{array}{l}\text { Rhanda Barry, Moore College } \\
\text { Vesna Cosic }\end{array}$ \\
\hline NZ Chapter: & President/Secretary/Treasurer & Helen Greenwood, St John's Collegc, Aucktand \\
\hline \multirow[t]{2}{*}{ Qld Chapter"; } & President & $\begin{array}{l}\text { Elizabeth Jordan, Trinity Theologieal College, } \\
\text { Auchenflower }\end{array}$ \\
\hline & Secretary/Treasurer & Carolyn Willasden, Pius X]I Seminary, Baryo \\
\hline SA Chapter: & $\begin{array}{l}\text { President } \\
\text { Secretary/Treasurer }\end{array}$ & $\begin{array}{l}\text { Trevor Zweck, Luther Campus, Nth Adelaide } \\
\text { Vat Canty, Parkin-Wesley Collegc, Wayville }\end{array}$ \\
\hline Vic Chapter: & $\begin{array}{l}\text { President } \\
\text { Secretary/Treasurer }\end{array}$ & $\begin{array}{l}\text { Tony McCimstic, Corpus Christic } \\
\text { Margaret Zarifeh, Prestylerian Theological } \\
\text { College, Box Hill }\end{array}$ \\
\hline WA Chapter: & $\begin{array}{l}\text { President } \\
\text { Vice President }\end{array}$ & $\begin{array}{l}\text { Alan Meers, Bible College, WA } \\
\text { Lynn White, Baptist Theological College, WA }\end{array}$ \\
\hline
\end{tabular}

